Article

\title{
From Maps to Stories: Dangerous Spaces in Agatha Christie's Homes
}

\author{
Debora A. Sarnelli \\ Department of Humanities, University of Salerno, 84084 Salerno, Italy; dsarnelli@unisa.it
}

Received: 27 November 2018; Accepted: 27 January 2019; Published: 31 January 2019

\begin{abstract}
In the common imagination, home denotes the physical space where human beings find protection, intimacy, and bliss. Home is a place of affection and warmth. This article proposes to analyze the perception of the place called home within Christie's narratives and how her fictional households are deprived of their protective value and become as blood soaked as the hard-boiled dirty back alleys. The article focuses on how every room occupies a different role in Christie's fictional houses. There are safe rooms-the busiest rooms of the household where murder never happens-and dangerous rooms. The dangerous room—-the murder scene-is described through the use of a map offered by the first-person narrator. The map provides the reader with important spatial information: this is the very place where the murder was perpetrated.
\end{abstract}

Keywords: detective fiction; Golden Age fiction; domestic space; home; maps; house plans

\section{Introduction}

During World War I Agatha Christie and Conan Doyle were writing detective fiction simultaneously. While a young and inexperienced Agatha Christie was giving life to a new detective hero, in 1917 Conan Doyle published a collection of short-stories, His Last Bow-already appeared on The Strand magazine. As the title itself suggests, the collection was initially conceived as the closing finale of the Holmes canon. However, due to the pressure of the readers, His Last Bow was followed by another collection of twelve short-stories, unified under the title of The Notebook of Sherlock Holmes. Agatha Christie's debut novel-The Mysterious Affair at Styles—appeared when Sherlock Holmes' fame was at its height. The young author completed the novel in 1916, when she was working as a voluntary nurse during World War I. The novel remained unread for almost four years. After being rejected by several editors, it was eventually published in 1920. It was a modest success. The reading audience was still tied up to the Sherlock Holmes tradition. The originality of The Mysterious Affair at Styles-a new detective hero strolling around a domestic space-was not appreciated.

The advent of The Mysterious Affair at Styles caused a break from the 19th-century tradition of detective fiction, which had been characterized by male heroes whose masculinity was employed as their basic point of strength. Hercule Poirot-Agatha Christie's most famous detective hero "of what later came to be termed the 'Golden Age' of detective fiction" (Stewart 2013, p. 102)—rejected the masculinity of his predecessors, introducing himself as the first antiheroic detective. "He is a parody of the male myth; his name implies his satirical status: he is a shortened Hercule and a poirot-a clown" (Munt 1994, p. 8). He is often described as a little man, and he is socially an outsider and 'the other', in the sense that he is a foreigner. He comes from outside the borders and is a Belgian refugee. From a geographical point of view, Belgium is often mistaken for a French dominion, perhaps because of its official language and its small size compared to bigger neighbors such as France, Germany, and the Netherlands. It is also a country of cultural and ethnic hybridity in contrast to the idea of English pure national identity. Poirot is frequently believed to be a French gentleman. The impossibility to identify Belgium within the map of Europe generates a sense of uncanniness among 
Christie's characters. Poirot introduces himself as a foreigner, and, as the critic Stephen Knight has noted, his odd and sometimes incomprehensible language together with his extravagant appearance separate him "from the society he helps" (Knight 1980, p. 118). Poirot's social status as 'the other' together with his buffoonish exterior create that uniqueness Agatha Christie was looking for. With Poirot's debut the Holmes-based qualities such as physical strength, bravery, and vitality gradually disappeared and a different hero detective, more human and similar to ordinary people, including women, was becoming the successor of the Holmesian detection legacy. However, Agatha Christie grew to despise Poirot intensely. She secretly killed him off in Curtain-a novel she wrote during the years of the Second World War-with the attempt to publish it posthumously. It was a relief for Christie to shape a new anti-hero detective, the ageless Miss Marple. Whereas Poirot is socially and geographically an outsider, Miss Marple is an insider, although her age and her status as a woman discriminate her. Thus, Poirot and Miss Marple do not share the same status. The two, however, share the same obsession towards domestic details and feminine practices, such as the recurrent use of gossip. Their vulnerabilities and physical weakness close the gap between reader and detective. From a superhero and a God-like figure, the detective transforms into an ordinary person. Whereas Sherlock Holmes's extravagancies-including his use of drugs-and his immense mental capacity and linguistic skills keep him at a distance from his readers, with the advent of Poirot and later with Miss Marple, the detective genre approaches the common readership. "The loss of Holmesian confidence democratizes the form and allows the puzzle genre to become something the reader is invited to enter on more equal terms" (Rowland 2004, p. 19). The identification of the murderer becomes a do-it-yourself operation, a challenge between the detective and his readers. Hence, Dame Christie, in the wake of the radical changes she imposed to the genre, shifted the setting of the action from the anonymous male city to the domesticated periphery, invading the marginal English villages "places conventionally demarcated as feminine" (ibid.), where the readers could easily feel at ease.

The Mysterious Affair at Styles-Poirot's debut novel-and The Murder at the Vicarage- the first novel to feature the character of Miss Marple-reveal Agatha Christie's fascination towards rural villages and enclosed spaces that recall the structure of an English country house. Agatha Christie was very fond of country houses. All her life revolved around the acquisition and the decoration of houses, a life-long passion which dates back to her childhood home in Torquay and which continues in adulthood, finding its best expression in the purchase of Greenway-her beloved holiday home. Her passion for houses is revealed in the Autobiography since her earliest memories as a child, when playing with the dollhouse was her favorite indoor pastime. When thinking about the past, she writes, "Looking back over the past, I become increasingly sure of one thing. My tastes have remained fundamentally the same. What I liked playing with as a child, I have liked playing with later in life. Houses, for instance" (AB, Christie 2001a, p. 60). Christie's fondness of country houses has affected her narratives to a point that every geographical location, whether in London, in the countryside or abroad, is shaped as an ideal country house, with its structure and closeness. The pattern she follows is always the same: a bounded place where a small assembly of people with no direct contact with the outside world is involved in a crime.

The research sheds a light on Agatha Christie's representation of houses, on how she structures her households into safe and dangerous spaces. Initially in this article, I will examine the novels The Mysterious Affair at Styles and Crooked House to show how Christie undermines the idea of the house's protective value. Subsequently, I shall focus on other four novels-The Murder of Roger Ackroyd, The Secret of Chimneys, The Body in the Library, and The Murder at the Vicarage- to demonstrate how the library/studio represents the most dangerous space within Christie's fictional households.

\section{The House as an Unhomely Place}

According to the Chinese-American geographer Yi-Fu Tuan, "places are centers of felt value where biological needs, such as those for food, water, rest, and procreation, are satisfied" (Tuan 1977, p. 4). Hence, home falls into the category of place theorized by the geographer. For Gaston Bachelard, 
the house is "the human being's first world and his [sic] first universe" (Bachelard 2014, p. 29). Without it, the human being would be a dispersed being. "It maintains him through the storms of the heavens and through those of life. It is body and soul" (ibid.). Before the human being is "cast into the world", she/he is laid in "the large cradle of the house [ ... ] Life begins well, it begins enclosed, protected, all warm in the bosom of the house" (ibid.). The house, the human being's personal place in the world, inspires protection and intimacy. The German philosopher Bollnow, following Bachelard's idea of the house's 'protective value', depicts the house as a secure place marked by protective walls and by a sheltering roof, where the walls delineate the separation between inner space-the space of security and outer space- the space of threat.

The outer space is the space for activity in the world [ ... ] it is the space of insecurity, of danger and vulnerability [ ... ] This is why he (the man) needs the space of the house. This is the area of rest and peace [ ... ] a space to which man can retire and where he can relax. To give this peace to man is the supreme task of the house (Bollnow 2011, p. 125).

The house, hence, offers reliable protection from danger "as well as from the unwelcome approach of strangers" (ibid., p. 126). Within the secure walls of the house, the human being constructs the smallest unit of society, where the first human relationships are shaped and where the individual personalities are created. The house then becomes the family home, the social space where humans first experience life. In Christie's narratives, the perception of the house conceived as a nurturing and safe place where to find shelter from the attacks of the outside world, is underlined at first and then drastically violated. The house, indeed, is deprived of its maternal function and security and it is quickly revealed as the opposite of homely (Light 1991, p. 92). Sigmund Freud opens his 1919 essay "The Uncanny" by giving a definition of what uncanny is: "belonging to all that is terrible-to all that arouses dread and creeping horror" (Freud 1925, p. 368). The father of psychoanalysis defines the uncanny in relation to the German words "Heimlich" or "homely", against the "unheimlich" or "unhomely". Freud writes that the terms "Heimlich" and "unheimlich" are used interchangeably to describe the uncanny. In fact, what is uncanny is both homely and unhomely. Unheimlich is not exactly the opposite of homely, but rather a term that designates a sense of estrangement within the home, the existence of something menacing and unknown that lies within the confines of the intimate. As a matter of fact, Heimlich relates to something which is known and familiar on the one hand and hidden and concealed on the other. According to Homi Bhabha the state of the "unhomely" is not a state of lacking a home, or the opposite of having a home, it is rather the creeping recognition that the line between world and home is breaking down; it is the alienating sense of relocating the home in an unfamiliar space. As Bhabha puts it:

In that displacement, the border between home and world becomes confused; and, uncannily, the private and the public become part of each other, forcing upon us a vision that is as divided as it is disorienting (Bhabha 1992, p. 141).

Bhabha's words depict the situation within Christie's country house novels, where the world perceived as a homeless place has penetrated deep into the domestic sphere. Whereas with Sherlock Holmes the dangerous places are located in the outside world-the only secure place in nineteenth century Victorian London is his home in Baker Street-Christie violates the idea of the house perceived as a safe microcosm. Moreover, her fictional houses are not constructed as a female-ordered world. She disrupts the Victorian image of the angel in the house through the lack of the maternal figure and violates Bachelard's idea of the house protective value. In her narratives the house is a fragile shelter. In The Mysterious Affair at Styles, the narrator, a young and injured Arthur Hastings on sick leave from the Front, introduces the reader to the geographical setting, giving a brief description of what type of place Styles Court is, namely the manor house of a neighboring village, Styles St. Mary. This is one of the few of Christie's country-house novels that are fixed in space: the story is set in Essex, during the First World War. The novel is both rooted in a particular real-world geography (the county of Essex), and creates fictional topographies (the village of Styles St. Mary). 
I descended from the train at Styles St. Mary, an absurd little station [ ... ] perched up in the midst of green fields and country lanes [ ... ] The village of Styles St. Mary was situated about two miles from the little station, and Styles Court lay a mile the other side of it (Christie 1995, p. 5).

In Hastings's recollection, no elements foreshadow the imminent tragedy. On the contrary, the first-person narrator informs the readers that he has often stayed at Styles Court during his youth, showing the familiarity he has with this large and isolated place. The remoteness of Styles Court from the war and the rest of the world highlights the sense of intimacy Hastings associates to the house. In the middle of the green English fields surrounding the estate, the reader is embraced by the comfortable feeling that nothing horrible can occur, that the world with its evils has been shut outside.

As one looked out over the flat Essex country, lying so green and peaceful under the afternoon sun, it seemed almost impossible to believe that, not so far away, a great war was running its appointed course. I felt I had suddenly strayed into another world. (ibid.)

Hastings has returned to Styles Court to find shelter and safety. The reader perceives the sense of protection felt by the narrator while contemplating the countryside. The war with its atrocities now seems far away, and Styles Court appears to the narrator's eyes as a safe harbor, a quite unattached microcosm where social stability and security have been preserved. As Robin Woods points out, Styles Court is "a fortress against the foreign engagements that the war presented and, more important, against the advancing forces of time" (Woods 1997, p. 105). The feeling of protection that both the narrator and the reader perceive is revealed as a mere illusion when the matriarch of Styles Court is poisoned. There is an assassin hiding within the house protective walls. From a secure place, the house becomes a place to escape from.

The 1949 novel Crooked House remains the most emblematic example of how Christie destroyed the myth of the house as a nurturing place. Here, the collapse of the boundaries between outer space and home intimacy together with the uncanny feeling associated with a familiar/unfamiliar place pervades the narration. The unhomely house of the title induces feelings of disorientation, ambiguity, and a profound sense of discomfort. The crooked house where the action takes place is a sprawling mansion called Three Gables located in Swinly Dean, close to Market Basing, described by the narrator as "the well-known outer suburb of London, which boasts three excellent golf courses for the city financier" (Christie 2014, p. 4). Three Gables was built at the beginning of the 20th century by Aristide Leonides, a Greek businessman, as a gift for his first wife and later divided into three separate houses where several generations of the Leonides family live together under the patriarch's wings.

One brother, one sister, a mother, a father, an uncle, an aunt by marriage, a grandfather, a great-aunt, and a step grandmother. [ ... ] Of course, we don't normally all live together. The war and blitzes have brought that about. But [ ... ] perhaps spiritually the family has always lived together-under my grandfather's eye and protection. (ibid., p. 4)

The crooked house presents a rigid spatial structure with space organized in accordance with the family's needs. The ground floor is occupied by Aristide's son Philip with Magda his wife and their three children: Sophia, Eustace, and Josephine. The first floor is dedicated to old Aristide and his second wife, the young Brenda, while his son Roger has occupied the upper floor together with his wife Clemency. The personalities of the occupants of Three Gables are presented through the descriptions of the drawing rooms of the three different apartments. Philip's drawing room is very eccentric, an expression of his actress wife's personality. The walls are covered with pictures of actors, dancers, stage scenes, and vases with flowers decorate the tables. As Clemency puts it, this room is "just a stage set. A background for Magda to play her scenes against" (ibid., p. 135). The drawing room in the first-floor apartment belonging to Aristide himself, is a less sophisticated but a comfortable room furnished with "colored cretonnes very gay in color and striped silk curtains [ ... ] and, in the middle, the portrait of a little man with dark piercing eyes" (ibid., p. 65). The portrait on the wall 
exemplifies the power of the patriarch. His eyes control the space of the house and, at the same time, the lives of the people living under his authority. The last drawing room, the one located on the upper floor apartment, is an expression of Clemency's scientist mind. The walls are all white, no pictures, no ornaments, and hardly any furniture. Charles-the amateur detective of the story-associates each drawing room to the personality of its occupants: "curious things rooms, they tell you quite a lot about the people who live in them" (ibid., p. 63).

Family matters and intrigue enliven this novel in which the least likely suspect formula has found one of its best expression when, in the concluding remarks, the young Josephine is discovered to be the only responsible for two murders. She is Philip's younger daughter, age eleven or twelve (ibid., p. 83): she is an ugly girl and not very feminine. She uses violence to protect herself and to gain power over her brother. She enjoys reading murder mysteries and listening at doors. Her family dislikes her to a point that no one puts in a nice word for her. "That child," Sophia says, "is a bit of a problem" (ibid., p. 98). "Sometimes I think that child isn't right in her head. She has horrible sneaky ways and she looks queer. She gives me the shivers sometimes" (ibid., p. 76), Brenda says. She is "a rotten kid" (ibid., p. 156) according to her brother Eustace and Charles himself, the narrator, labels her as a "malicious gnome" (ibid., p. 119) who "had the suddenness of a demon in an old-fashioned pantomime" (ibid., p. 161). There is no sympathy for her not even from her mother Magda, who has no words of affection for her child, other than "my funny ugly baby" (ibid., p. 178) and, "curious changeling" (ibid., pp. 178-79, 216, 238).

Josephine's deviant behaviors are the result of several causes which have blended and given life to a violent and cruel child. Traditionally, the family home plays the major influence in shaping one's life and one's perception towards the outer world. The family primarily encourages the child's attitude and beliefs because it is in the home, with the family, where the child first learns the essential lessons in life. Hence, how the child behaves in the home and in the society is a result of the values acquired from the family. Josephine's family and home are crooked, as the title suggests. The house has "a strange air of being distorted" (ibid., p. 26), described by the narrator as "a cottage swollen out of all proportion. It was like looking at a country cottage through a gigantic magnifying glass-it was a little crooked house that had grown like a mushroom in the night!" (ibid.). The "crookedness" runs in the family blood. The patriarch, Aristide Leonides, is frequently described as being "crooked". Sophia, Leonides' granddaughter, insists: "we're a very queer family" (ibid., p. 29). Aristide's two sons have decided to live at Three Gables for convenience-the wealthy patriarch contributes to their financial needs, being the family's only source of income. Its residents have no values and they fail to follow the traditional roles-Josephine's parents, for instance, are passive and static characters, they are more artists than parents, locked in their imaginary worlds (he writes pseudohistoric books, she is always busy playing the role of the actress). The absence of a typical mother-daughter relationship lies heavy on the little girl, brought up by her aunt Edith and by a tireless nannie. The child of an unreliable and cruel mother, Josephine has grown up unscrupulous and ruthless.

Grandfather wouldn't let me do bally dancing so I made my mind I would kill him [ ... ] I don't want to go to Switzerland. If mother makes me, I will kill her too [ . . ] Nannie's dead. I am glad. I haven't decided yet where I'll hide the bottle with the little pill things. (ibid., pp. 239-40)

Josephine shows her bad temper and her poor coping skills by planning to kill those people who make her angry. She killed her grandfather because he would not let her take ballet lessons and killed her devoted nanny because she called her "a silly girl". Her confessions also reveal her future intentions to kill her mother. The home which should protect the child from dangers, in the end transforms the child into a murderer. The ruthlessness running in the family blood has deprived the home of its nurturing role. The house that is supposed to provide protection to its dwellers reveals its fragility. The lack of a sense of belonging and of affection transmutes home into a place of violence, a place to escape from. In Crooked House home and family fail to provide stability and a bounded reassurance. Due to the patriarch's tyranny over their lives, every family member, including the 
young Josephine, has grown crooked, under the crooked man, in his crooked mansion on the outskirts of London.

\section{Dangerous and Safe Places}

Christie's homes are usually constructed from her memories of both Ashfield, her childhood home in Torquay, and of the several country houses she visited, inhabited and purchased during her life. From the outside her imaginary family homes usually look like grandiose premises, surrounded by massive gardens, carefully planted lawns, distinctive terraces, and centuries-old trees. The interior spaces are divided in a library, drawing rooms, dining rooms, bedrooms (usually on the upper floor), vast corridors, and huge staircases and, like any self-respecting English country house, a special space reserved for servant quarters, where the action never takes place. The houses are U-shaped or L-shaped, contain two wings while their maps, usually provided by the first-person narrator, constitute a very important part of the novel.

Agatha Christie employed maps from the very beginning of her career. In The Mysterious Affair at Styles Court Captain Hastings offers a map to the readers, indicating the family arrangements during the night when the matriarch is poisoned in her sleep. "To make this part of my story clear, I append the following plan of the first floor of Styles" (Christie 1995, p. 42), says Hastings, and introduces it within the narration. The map (Figure 1) illustrates the upper floor of the mansion-the downstairs floor was reserved for social life. Every room is labeled, including the one where the crime is committed (the room indicated by a red arrow). The map demonstrates how the family members have ready access to the crime scene using three separate doors.

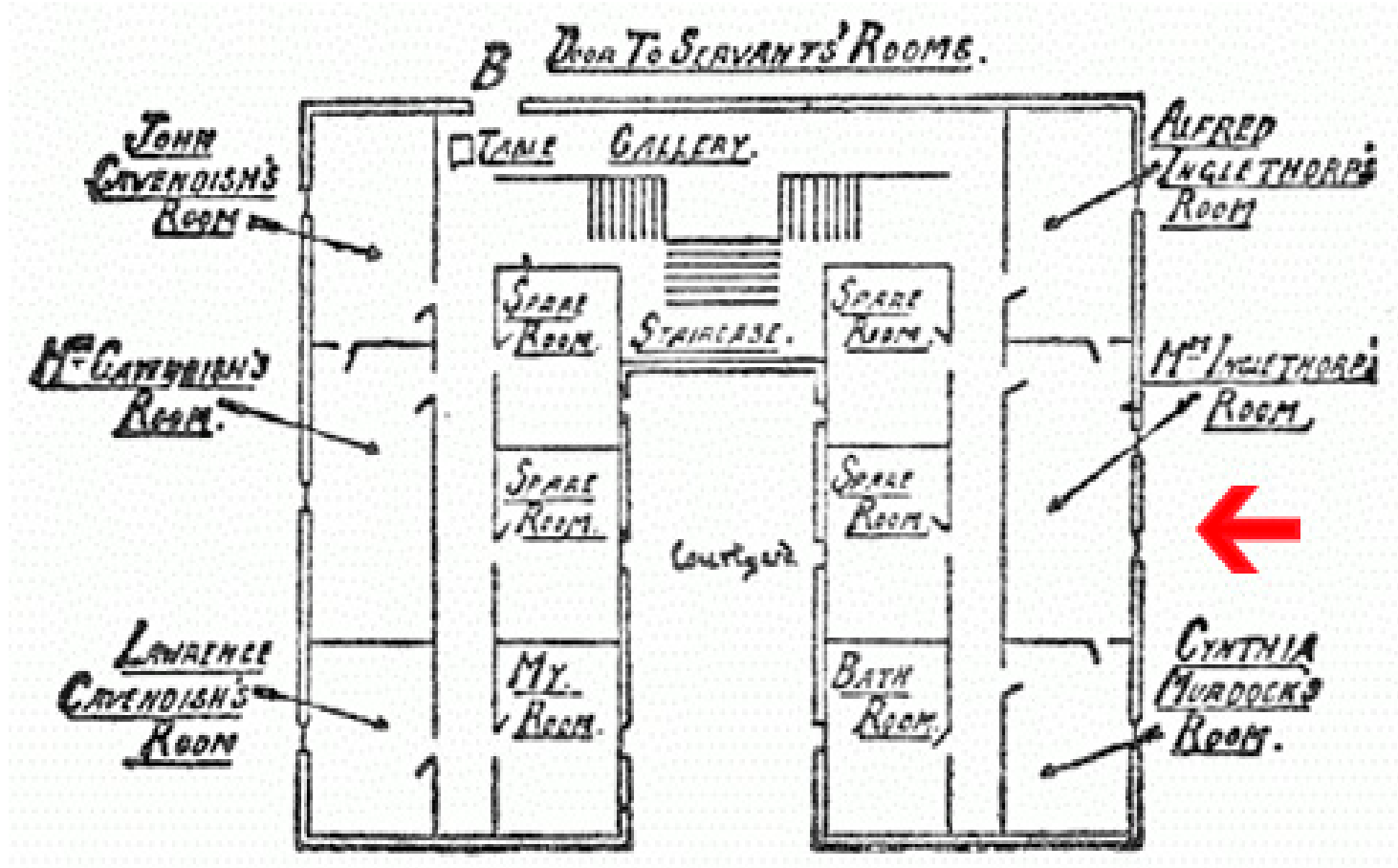

Figure 1. The map of Styles Court, provided by Captain Hastings, the night of the murder.

As the story unfolds and Hercule Poirot, who happens to live in the village of Styles St. Mary as a Belgian refugee, is given the task of solving the intricate mystery, Captain Hastings draws an additional map, this time focusing on the detailed representation of the interior space of Mrs. Inglethorp's bedroom, the scene of the crime (Figure 2). The map is provided, in this case, at the beginning of Poirot's investigation. 


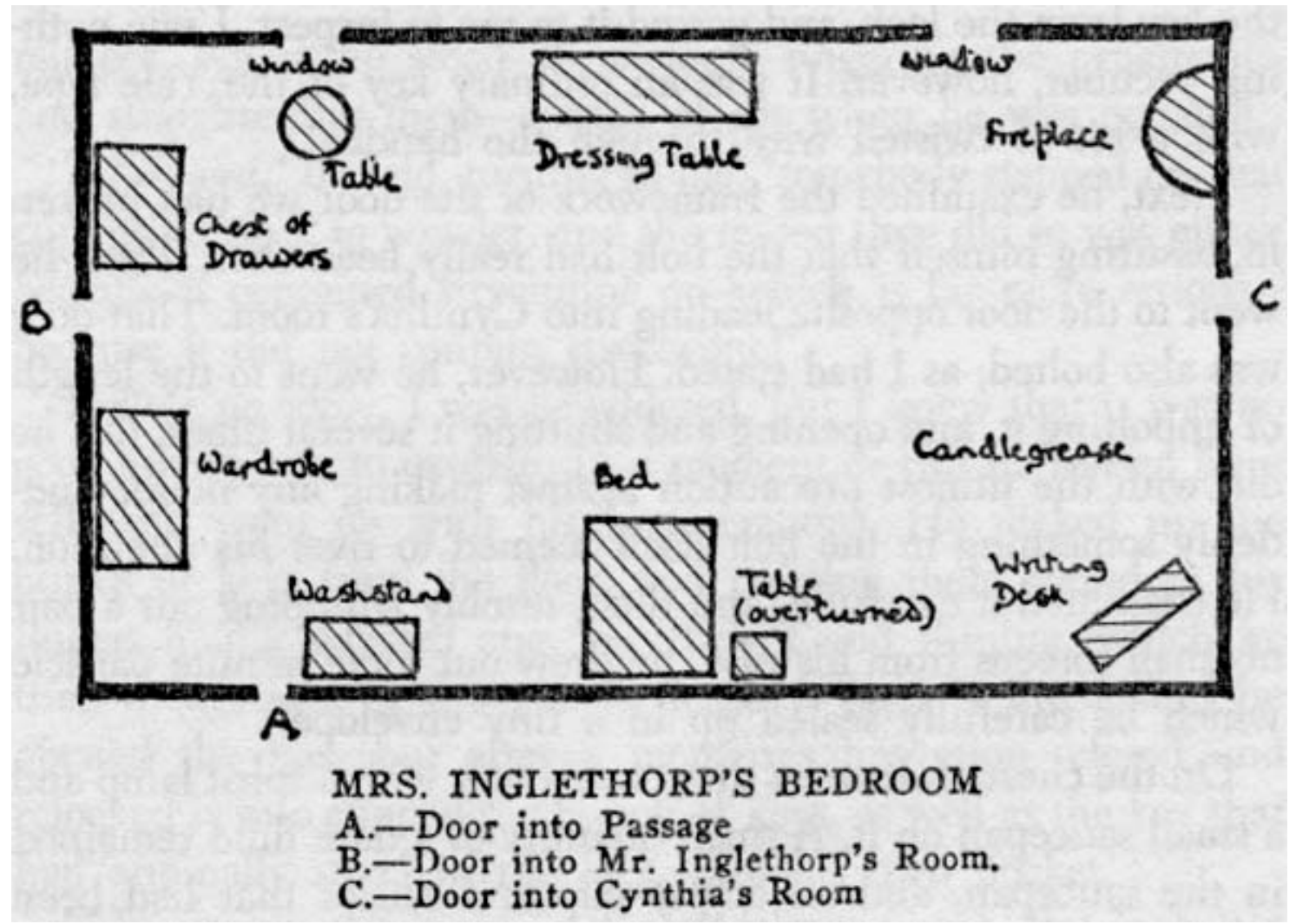

Figure 2. Map of the scene of the crime.

The two maps, according to Sally Bushell, delineate Tzvetan Todorov's dual temporal and narrative structure. The first map (the floor plan-Figure 1) relates to the conclusion of the first narrative-Todorov calls it the story of the crime-while the second map (the victim's bedroom-Figure 2) marks the beginning of the second narrative-the story of the investigation (Bushell 2012, p. 156). The detective leading the second story needs to travel into past events to solve the crime. His investigation involves a particular "mapping out of spatial and human relations to reconstruct the first structure and so resolve the narrative. Only once everything is 'in place' can the truth emerge" (ibid., p. 155).

The use of maps and house plans became a very common practice during the Golden Age, when the detective genre came to be associated with the fair play rule. In this respect, Robert Barnard in $A$ Talent to Deceive writes, "We are entering the age when plans of the house were an indispensable aid to the aspirant solver of detective stories" (Barnard 1990, p. 23). Readers were challenged to participate in the solving process at the side of great detectives and encouraged to read and interpret the maps rather than merely looking at them. Christie's fiction and her recurrent use of maps activates the reader response. Readers, indeed, always go back to look at the map in order to locate the characters. Agatha Christie employs them again in 1926 in The Murder of Roger Ackroyd, the novel that consecrated her as the Golden Age's greatest writer. Although diverging opinions exist as regards the classification of the novel as a masterpiece-back in 1926 it was condemned as a cheat by several members of the Detection Club (Knight 1980, p. 112) —readers from all over the world are still fascinated by its twisting and controversial ending.

Figure 3 presents two first edition maps included in the novel: on the left a floor plan of the house and its surroundings, and a detailed plan of the murder scene on the right. As it has been the case with The Mysterious Affair at Styles Court, in The Murder of Roger Ackroyd the maps are provided by the first-person narrator, Dr Sheppard, who occupies Hastings' role as Poirot's inexpert sidekick. "'You must indeed have been sent from the good God to replace my friend Hastings', he said, with a twinkle. 
'I observe that you do not quit my side'" (Christie 2013, p. 101), Poirot comments when he assumes the role of the investigator. The formula Dr Sheppard uses to justify the presence of the maps reminds Hastings' words in The Mysterious Affair at Styles Court. Dr Sheppard explains: "To make things clear and explain the position, I have appended a rough sketch of the right-hand wing of the house" (ibid., p. 58). In The Murder of Roger Ackroyd, however, the map of the murder scene is misleading because is provided by the murderer. Poirot reconstructs the night of the crime referring to the grandfather chair located by the door of the victim's study/library. The narrator, unmasked as the culprit, has moved it from its original place to hide his involvement in the murder. Hence, the map he presents alters the reality by reproducing what the murderer wants the reader-and the detective-to see. There is an interesting intersection here between the acts of narration, crime-solving, and map-making, all three performed by the same character. Moreover, as Stephen Knight has observed, Poirot solves the case thanks to a great sense of time and place. Dr Sheppard has taken "too long to move from the front door to the gate of Ackroyd's house" (Knight 1980, p. 119).
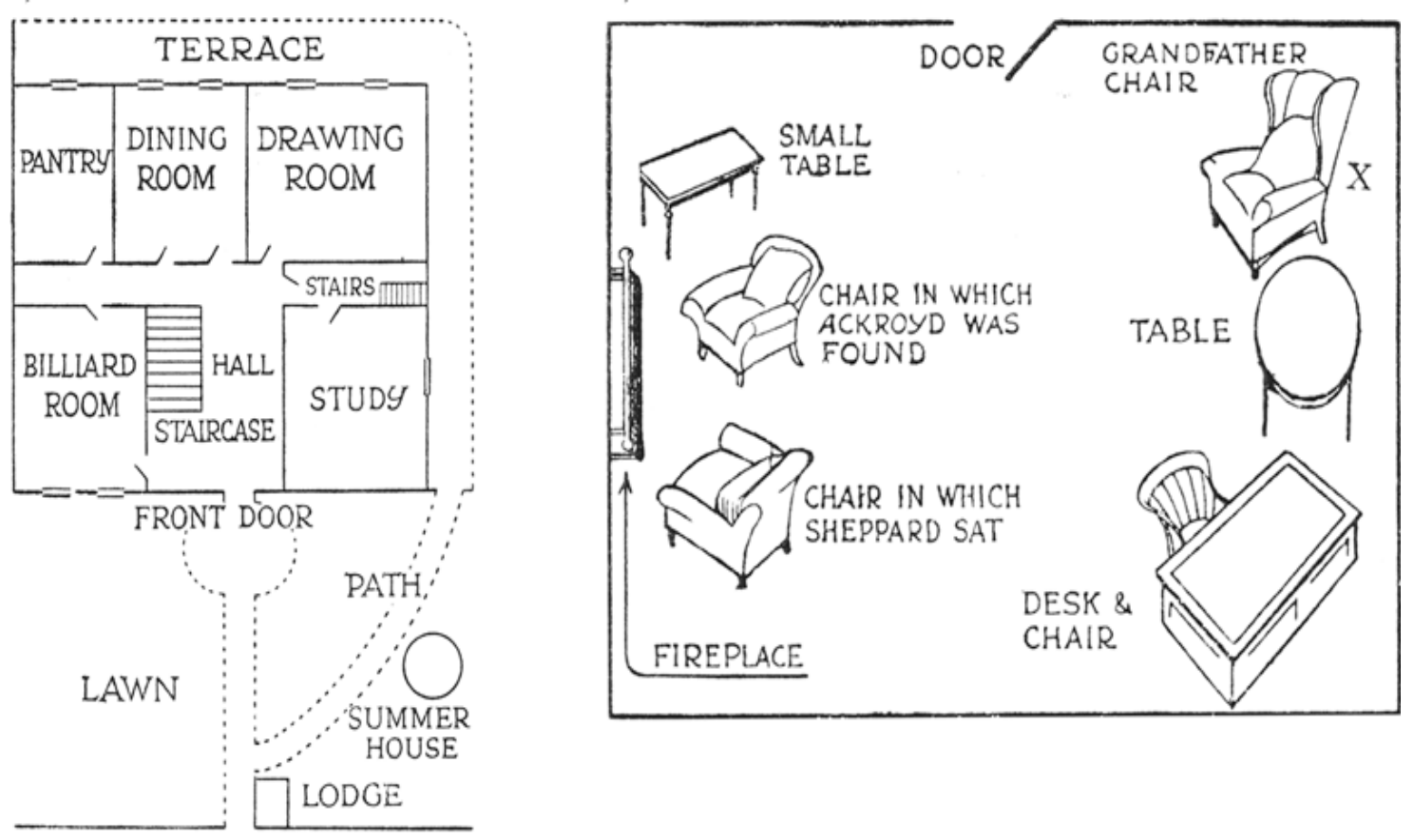

Figure 3. Map of the house plan and of the study where Ackroyd is killed.

The intent of Christie's maps, writes Bargainnier, "is to create greater verisimilitude: the place exists in space; here is where it happened" (Bargainnier 1980, p. 25). In fact, Christie's maps clarify the spatiality of the genre, underlining that the murder occurred in that specific place. The domestic space of her novels is divided into several distinct zones: dangerous and safe places. Murders, indeed, do not occur in every room of the house. Each one of them has its symbolic status. Looking at the scenes of the crime in the maps of The Mysterious Affair at Styles Court (Figure 2) and The Murder of Roger Ackroyd (Figure 3), the victims are killed respectively in the bedroom and in the library-study. In Christie's domestic households, undeniably, the most dangerous spaces are the libraries and the bedrooms. According to Maida and Spornick, libraries and studios are dangerous for differing reasons (Maida and Spornick 1982, p. 183). The library/study is not as busy as the drawing room, and it is often open and accessible to everyone. Characters can get in or out passing through its large windows-in The Murder of Roger Ackroyd and in The Secret of Chimneys the large French windows, for instance, provide an easy escape for the murders. Its dusty shelves and cupboards can conceal secret letters and personal diaries behind ancient books. Furthermore, the fireplace-every library was provided with one-can destroy incriminating clues and inconvenient wills. In The Secret of Chimneys, where Chimneys is the 
ancestral country house where the events take place, the murder occurs in the Council Chamber, a library that hides a secret passage leading to Wyvern Abbey (Christie 2001b, pp. 309-10). Whereas in The Body in the Library it is inside this impersonal space where the corpse of a young blond woman is found "sprawled across the old bearskin hearthrug" (Christie 2002, p. 21), wrapped in cheap dancer clothes, in the respectable house of the richest people of St. Mary Mead. "[S]he doesn't look real at all" (ibid., p. 19), Mrs. Bantry exclaims on the phone to Miss Marple. Indeed, the countenance of the girl clashes with the elegance of the locale in which she interferes. She is an element of disturbance. As such, it is evident that she belongs to an inferior social class and that her presence destroys the order and the harmony commonly associated with the library. In the foreword to her novel, Christie argues that "the library in question must be a highly orthodox and conventional library. The body, on the other hand, must be a wildly improbable and highly sensational body" (ibid., p. 7). The incongruity is evident: the victim is transgressive, young, sensual, and poor, denoting the deep gap between her class and the upper middle class world of the Bantry family.

In The Secret of Chimneys, the library is presented as a mysterious room, richly furnished with important paintings on its walls, including two Van Dycks and a Velazquez (Christie 2001b, p. 170). A spring concealed at the side of a family portrait reveals a dark opening leading to a secret underground tunnel which, in some respects, evokes Gaston Bachelard's perception of the cellar. The French philosopher, whose work The Poetics of Space applies the method of phenomenology to the architectural space of the house, argues that the cellar "is first and foremost the dark entity of the house" (Bachelard 2014, p. 39) and the place of irrationality and the unconscious. The cellar as a mysterious place where darkness prevails both day and night and where fears become exaggerated. In The Secret of Chimneys, the labyrinthine obscure corridor epitomizes the dark entity of the estate, in line with Bachelard's expressed ideas, a space long been shut from the outside world. The reader in it, to use Bachelard's words, is "in the intimate space of underground maneuvers" (ibid., p. 43). The peculiarity in The Secret of Chimneys is the fact that the secret passage, apart from being the dark entity of the home, is the limbo space between reality and legends and is somehow connected to a mystery going back seven years, and to a consequent homicide. The library milieu also provides the possibility to employ bizarre and exotic murder weapons, usually gifted to the patriarch by friends or souvenirs bought during trips abroad. For instance, Roger Ackroyd is stabbed within his library with a Tunisian dagger, a beautiful, ornate blade belonging to Roger's personal collection, stolen by the assassin during a visit to the house.

Likewise, the library proves to be, once more, a dangerous room in Miss Marple's debut novel The Murder at the Vicarage.

Figure 4 captures the layout of the vicar's study. It is provided with a fireplace, as Roger Ackroyd's study and it is located away from the busiest rooms of the house. The study is readily accessible to anyone. Hence, when Colonel Protheroe-one of the wealthiest men in St Mary Mead-arrives at the vicarage and the vicar is not in, the maid invites him to take a seat in the study (Christie 1997, p. 533). Having in mind to write a note, he places himself at the writing table, on the right side of the bookshelf, where he will meet his death. The homicide inevitably links together the two most notorious households of the village: that of the vicar Leonard Clement, who also serves as the first-person narrator of the events, and the country house of Old Hall, home to wealthy Colonel Protheroe, his second wife Anne and his daughter Lettice. Whereas at the Vicarage life is characterized by a vivid domesticity, life at the Hall is static and unhappy. The Colonel's murder is planned in every minimum detail, where time and place/space mingle together. Its solution will be the result of the enigma of the vicar's clock kept a quarter of an hour ahead and of the movements of the characters within the community space. 


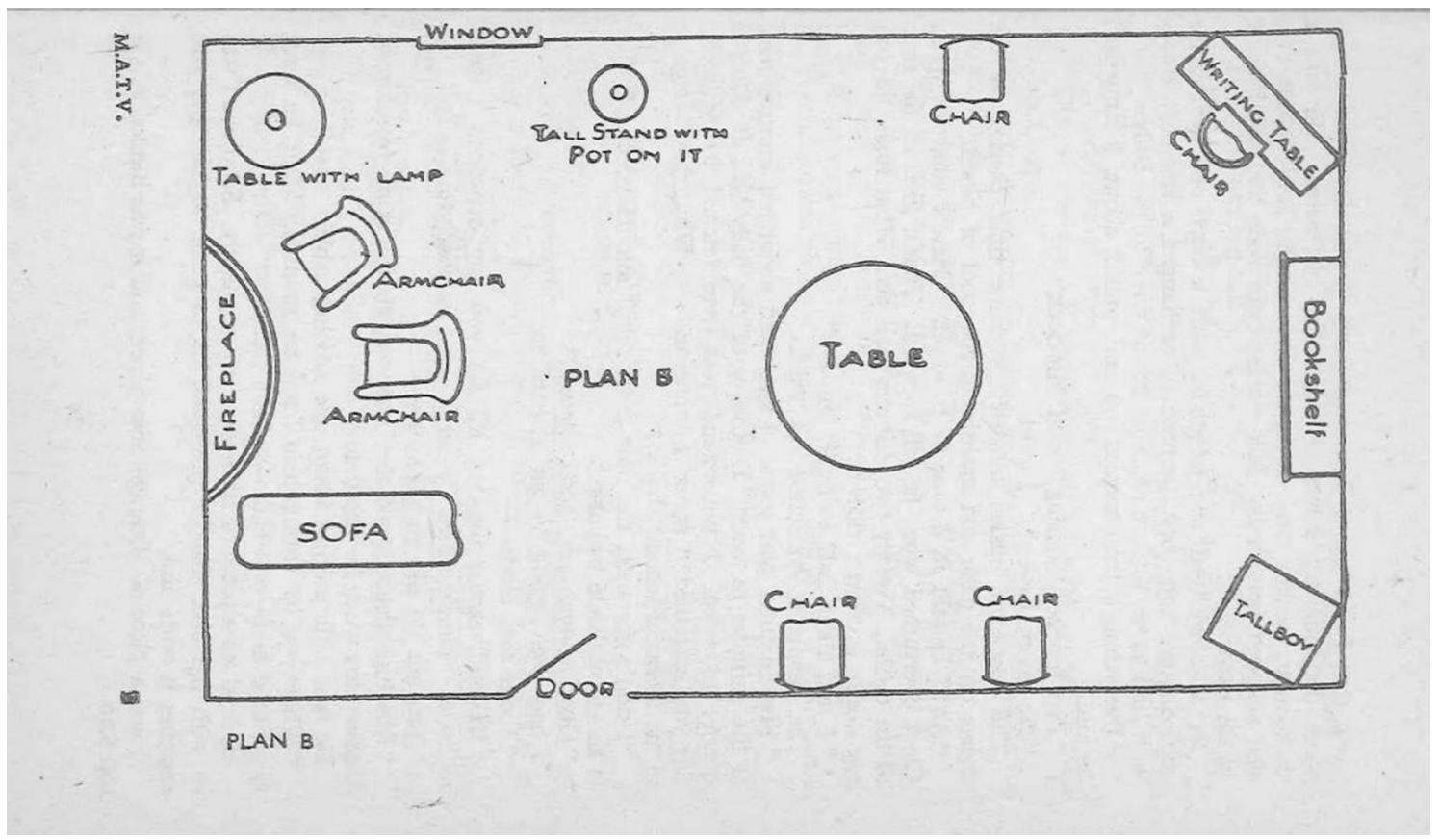

Figure 4. Map of the vicar's study where Colonel Protheroe is killed.

Clearly Christie has deprived the library of its essential role within the country house. In the typical English manor house, the library was an indispensable room for the educated gentry. Constructed as an exclusive male domain which women would only visit when invited (Durant 1996, p. 189), it was the perfect room where men could pursue hobbies, read in tranquility, and smoke a cigar away from the noisy spaces of the drawing room (Phillips 1988, p. 122). Libraries were always furnished with splendor. Cupboards and shelves filled with books of bygone eras, precious manuscripts and collections were valuable possessions and the prerogatives of every country house library. It was a status symbol and its importance grew particularly during the reign of Queen Victoria, when both literacy and the value of education were becoming more appreciated, and family book collections were outgrowing in number. The motif of a dead body in such restricted but élite places becomes more and more frequent in the Golden Age whodunit subgenre, when the brutality of a murder must perturb the domestic and family centered world. A violent assassination clashes with the refinement and the elegance of the antique country house. Its magnificent library, "a classic image of social order" (York 2007, pp. 13-14), where the discovery of "the body must suggest the scandalous and disreputable" (ibid.), and where to quote W. H. Auden, "the corpse must shock not only because it is a corpse but also because, even for a corpse, it is shockingly out of place [ . . ]" (Auden 1948, p. 408).

The same aura of peril surrounds the master's bedroom, the place that delineates the intimate area of life. Its isolated position from the communal life of the downstairs floor makes it easier for intruders to enter the room furtively. Here they can search for any incriminating evidence or alter medicines through the addition of poison. It is a solitary place where secrets, lies, and keys are concealed, a room full of drawers, chests, and wardrobes: "all hiding-places in which human beings [ . . ] keep or hide their secrets" (Bachelard 2014, p. 95). The bedroom, like the library, is usually provided with a fireplace that, where appropriate, is used to destroy evidences, uncomfortable wills and incriminating letters. The bedroom is the reign of the matriarch or the patriarch and their death is commonly caused by poison while they are locked in their apparently safe and secure territory. In The Mysterious Affair at Styles Court the victim, Emily Inglethorp, dies in her bedroom - but the homicide is prepared well in advance by adding bromide powders to the victim's medicine, causing a large amount of strychnine to be taken in the final dose. Something similar happens to the victim in Crooked House, where the patriarch, Aristide Leonides, dies in the comfort of his bedroom, poisoned with his own eye medicine via an insulin injection. 
The drawing room and the kitchen are the safest rooms in Christie's fictional houses. Comfortable and warm, the drawing room was the main living area of the household, where the inhabitants and the house guests would meet before dinner, gather, sing and play music, converse or play communal games or cards (Phillips 1988, p. 114). The drawing room was the space reserved for meetings and for other social events. Frequently, Christie's houses include more than one drawing room. For instance, in Crooked House the household is divided in three separate apartments, each one of them with a private drawing room.

A separate world from the rest of the house, the kitchen was not designed for living in but simply for work. It was a place destined to the servants and family members hardly ventured in it. In Agatha Christie's country houses, the kitchen corresponds to the safest place, where murders never occur (Maida and Spornick 1982, p. 184). It occupies a peripheral position compared to the other rooms of the house and is usually dwelled by the servants, who always play a very marginal role in Christie's narratives. The sanctity of this place is never violated by unscrupulous murderers and the tragic events of the household do not affect the rituals of breakfast and dinners. For Christie food is a fundamental part of the setting and, at the same time, it is a constant factor of her narratives. Food, according to Larmouth, "serves an important function in giving a sense of reality" (Larmouth 1972, p. 3) and in many cases, a sense of normalcy and domesticity. The proper English breakfast and the ceremony of the afternoon tea with biscuits, milk, and honey, are often described within her novels underlining Christie's preoccupation with notions of England and Englishness. These traditional rituals continue undisturbed and many characters refuse to speak of murder during mealtimes. It is not accidental that Christie's detectives and criminals are often described while drinking tea or eating delicious cakes. However, Christie reminds us that food can be easily deprived of its vital force and altered into a murder weapon. When this is the case, food becomes a vehicle for poison and loses its traditional cultural symbolism of safety and domesticity (Baucekova 2014, p. 39). The author's fascination for food accompanies the reader throughout Christie's vast collection of detective fiction. For the detectives and the readers food provides a temporary relief from the uncertainties and vulnerabilities of human relationships, from the blood and chaos of murder and violence. The safe ritual of eating temporarily interrupts the investigation, increasing the suspense, as the detective transmutes the dining pause into an occasion to reflect about the occurrences. Furthermore, food humanizes the detectives and at the same time gives a sense of reality to the world they investigate.

\section{Conclusions}

Agatha Christie's representation of houses denotes the writer's penchant for the domestic space. Her households are geographically isolated from the rest of the society. The entire narration of the events unfolds within the bounded setting of the house. In The Mysterious Affair at Styles and in Crooked House the house is so important to totally eclipse the town where it is located. The country houses of Styles Court and Three Gables are first presented as harmonious paradises, as microcosms where order and social stability have been conserved. However, this initial feeling of protection the reader perceives is soon revealed as a mere illusion when a murder destabilizes the family home. Likewise, the article has examined how libraries and studies are usually the most dangerous rooms within Christie's households and how the author's use of maps within the novels covers a fundamental role: maps are used to locate the characters' movements within the narrative space. Moreover, they delimit the space of the action which is reduced to manageable dimensions: the events develop within the borders of the map whereas the outside world is excluded from the narration. The map pinpoints the precise place where the murder is committed, investigated, and solved. The detective-and the reader-must search for the guilty party within the closed circle of suspects, among those characters dwelling the domestic space. In fact, in Christie's oeuvre the murderer is never an outsider, but becomes 'one of us'. Therefore, murder becomes a family matter and invades those places generally demarcated as secure. Home loses its protective function and becomes a fragile shelter. The known and familiar world of the 
house reveals its unhomely side. Offering no refuge from wickedness, home becomes a microcosm where greed and anger are concealed behind the mask of hypocrisy.

Funding: This research received no external funding.

Conflicts of Interest: The author declares no conflict of interest.

\section{References}

Auden, Wystan Hugh. 1948. The Guilty Vicarage: Notes on the Detective Story by an Addict. Harper's Magazine. pp. 406-12. Available online: https:/ /harpers.org/archive/1948/05/the-guilty-vicarage/2/ (accessed on 9 November 2018).

Bachelard, Gaston. 2014. The Poetics of Space. Translated by Maria Jolas. New York: Penguin Group.

Bargainnier, Earl. 1980. The Gentle Art of Murder: The Fiction of Agatha Christie. Bowling Green: Bowling Green University Popular Press.

Barnard, Robert. 1990. A Talent to Deceive: An Appreciation of Agatha Christie. London: Fontana.

Baucekova, Silvia. 2014. The Flavour of Murder: Food and Crime in the Novels of Agatha Christie. Prague Journal of English Studies 3: 35-46. [CrossRef]

Bhabha, Homi. 1992. The World and the Home. Social Text 10: 141-53. [CrossRef]

Bollnow, Otto Friedrich. 2011. Human Space. Translated by Christine Shuttleworth. London: Hyphen Press.

Bushell, Sally. 2012. The Slipperiness of Literary Maps: Critical Cartography and Literary Cartography. Cartographica 47: 149-60. [CrossRef]

Christie, Agatha. 1995. The Mysterious Affair at Styles. London: HarperCollins Publishers.

Christie, Agatha. 1997. The Murder at the Vicarage. London: HarperCollins.

Christie, Agatha. 2001a. An Autobiography. London: HarperCollins Publishers.

Christie, Agatha. 2001b. The Secret of Chimneys. London: Harper UK.

Christie, Agatha. 2002. The Body in the Library. London: HarperCollins Publishers.

Christie, Agatha. 2013. The Murder of Roger Ackroyd. London: HarperCollins Publishers.

Christie, Agatha. 2014. Crooked House. London: HarperCollins.

Durant, David. 1996. Life in the Country House. London: John Murray.

Freud, Sigmund. 1925. Collected Papers. Volume IV. London: The Hogarth Press.

Knight, Stephen. 1980. Form and Ideology in Crime Fiction. London: Macmillan.

Larmouth, Jeanine. 1972. Murder on the Menu. New York: Scribner.

Light, Alison. 1991. Forever England: Femininity, Literature and Conservatism between the Wars. New York: Routledge.

Maida, Patricia D., and Nicholas B. Spornick. 1982. Murder She Wrote. A Study of Agatha Christie's Detective Fiction. Bowling Green: Bowling Green University Popular Press.

Munt, Sally R. 1994. Murder by the Book? Feminism and the Crime Novel. London and New York: Routledge.

Rowland, Susan. 2004. From Agatha Christie to Ruth Rendell: British Women Writers in Detective and Crime Fiction. Basingstoke: Palgrave.

Phillips, Barty. 1988. The Country House Book. Topsfield: Salem House.

Stewart, Victoria. 2013. Defining Detective Fiction in Interwar Britain. The Space between: Literature and Culture 1914-1945 9: 101-18.

Tuan, Yi-Fu. 1977. Space and Place: The Perspective of Experience. Minneapolis: University of Minnesota Press.

Woods, Robin. 1997. It Was the Mark of Cain: Agatha Christie and the Murder of the Mystery. In Theory and Practice of Classic Detective Fiction. Edited by Jerome H. Delamater and Ruth Prigozy. Westport: Greenwood Press, pp. 103-10.

York, Richard A. 2007. Agatha Christie: Power and Illusion. Basingstoke: Palgrave Macmillan.

( 2019 by the author. Licensee MDPI, Basel, Switzerland. This article is an open access article distributed under the terms and conditions of the Creative Commons Attribution (CC BY) license (http://creativecommons.org/licenses/by/4.0/). 